\title{
Adaptogenic Activity of Lyophilized Hydroethanol Extract of Pandanus odoratissimus in Swiss Albino Mice
}

\author{
Prafulla P. Adkar, ${ }^{1,2}$ Pranita P. Jadhav, ${ }^{1}$ Shirishkumar D. Ambavade, ${ }^{1}$ \\ V. H. Bhaskar, ${ }^{3}$ and Tushar Shelke ${ }^{4}$ \\ ${ }^{1}$ Post Graduates Department of Pharmacology, JSPM's Jayawantrao Sawant College of Pharmacy and Research, \\ University of Pune, Pune, Maharashtra 411028, India \\ ${ }^{2}$ Vinayaka Missions University, Sankari Main Road, NH-47, Ariyanoor, Salem, Tamil Nadu 636308, India \\ ${ }^{3}$ Department of Pharmaceutical Medicinal Chemistry, Gahlot Institute of Pharmacy, Plot No. 59, Sector No. 14, \\ Koparkhairane, Navi-Mumbai, Maharashtra 400709, India \\ ${ }^{4}$ JSPM's Charak College of Pharmacy and Research, University of Pune, Pune, Maharashtra 412207, India
}

Correspondence should be addressed to V. H. Bhaskar; vhbhaskar@gmail.com

Received 16 April 2014; Revised 16 July 2014; Accepted 6 August 2014; Published 29 October 2014

Academic Editor: Federica Pellati

Copyright (c) 2014 Prafulla P. Adkar et al. This is an open access article distributed under the Creative Commons Attribution License, which permits unrestricted use, distribution, and reproduction in any medium, provided the original work is properly cited.

\begin{abstract}
Background. The leaves of Pandanus odoratissimus Linn have been widely used in Ayurveda to treat a variety of common and stress related disorders. In the present investigation, hydroethanol extract of leaves of Pandanus odoratissimus Linn (LEPO) were evaluated for antistress activity in normal and stress induced mice. Furthermore, the extract was studied for nootropic (adaptogenic) activity in mice and in vitro antioxidant potential to correlate with its adaptogenic and antistress activity. LEPO (100 and $200 \mathrm{mg} / \mathrm{kg}$ p.o) was evaluated against forced swimming endurance stress test, anoxia stress tolerance and immobilization stress and chronic cold resistant stress tests, and biomarkers (serum glucose, Corticosterone, WBC, RBC, and DLC count) to assess the antistress activity in mice. Withania somnifera (WS) $(100 \mathrm{mg} / \mathrm{kg}$ p.o) was selected as reference standard. The parameters like anoxia stress tolerance time were recorded in anoxia stress and estimation of biochemical marker levels and determination of organs weight were carried out in immobilization stress models. Results. Concomitant treatment with LEPO $200 \mathrm{mg} / \mathrm{kg}$ significantly increased in anoxia stress tolerance time. Dose dependent significant reduction in serum glucose, corticosterone, and WBC, RBC, and DLC was observed in immobilisation stress model as compared to stressed group. LEOP $200 \mathrm{mg} / \mathrm{kg}$ and WS $100 \mathrm{mg} / \mathrm{kg}$ significantly reversed/inhibited the stress induced changes in these parameters. The results from the present study indicate that these values also express that dose dependent significant adaptogenic activity in stressed animals. Conclusion. The present study provides scientific support for the antistress (adaptogenic) and nootropic activities of lyophilized hydroethanol extract of Pandanus odoratissimus Linn and substantiate the traditional claims for the usage of Pandanus in stress induced disorders.
\end{abstract}

\section{Introduction}

According to the report of WHO, approximately 450 million people suffer from mental or behavioral disorders like stress. This amounts to $12.3 \%$ of the global burden of disease and is predicted to rise up to $15 \%$ by 2020 . It is estimated that $75-$ $90 \%$ of visits to primary care physicians are related to stress either acutely or because of chronic problems associated with stress. An October 2008 American Psychological Association (APA) press release on stress in America claimed that 8 of 10 Americans cite the economy as a significant source of stress, up from 66 percent six months earlier. In June 2008 , more people were reporting symptoms associated with stress compared to the previous year, with nearly half polled indicating that stress had increased in the past years [1].

Stress is nonspecific response of the body known to alter the physiological homeostasis of the organism resulting in various neuronal, endocrine, and visceral dysfunctions. The ability to develop and maintain resistance against a variety of stressors encountered in human life is crucial for survival [2]. 
If stress increases the organism may become diseased. Stress is one of the basic factors which cause a number of diseases such as atherosclerosis, coronary heart disease, aging, and liver disease [1]. The desire to control the coping mechanisms has led to the origin of the science of adaptation [2].

Physiologists define stress as how the body reacts to a stressor, real or imagined, a stimulus that causes stress. Acute stressors affect an organism in the short term; chronic stressors over the longer term selye researched the effects of stress.

If exhaustion is extended, long term damage may result as the body and the immune system are exhausted and function is impaired resulting in decompensation. The result can manifest itself in obvious illnesses such as ulcers, depression, diabetes, and trouble with the digestive system or even cardiovascular problems, along with other mental illnesses [3].

Adaptogens are substances that help organisms to adapt to unfavorable stressful conditions, which could be physical, chemical, biological, or mental conditions. Some pioneer researchers in this field put forth specific criteria that need to be fulfilled to qualify as an adaptogens, which include ability to produce a nonspecific response (i.e., increases resistance against multiple physical, chemical, or biological stressors); it brings any dysfunctioning body system back into balance and must be innocuous, that is, must not influence normal body functions more than required. Adaptogens could be synthetic or natural substances. However, most researches on adaptogens have focused on natural substances (specifically plants), and the term "phytoadaptogens" is now commonly used for adaptogens of plant origin [2].

The Ayurvedic plant Pandanus odoratissimus Linn belonging to the family Pandanaceae Pandanus comprises 500600 species and is distributed mainly in subtropical and tropical regions; out of these, 36 species have been recorded in India. It is widely distributed in India over coastal districts of Orissa (especially in Ganjam), Andhra Pradesh, Tamil Nadu, and to some extent in parts of Uttar Pradesh.

Preliminary phytochemical analysis positive tests for alkaloids, steroids, carbohydrates, phenolic compounds, glycosides, proteins and amino acids, and so forth [4]. Pandanus odoratissimus contain the active chemical constituents which serve the medicinal properties: 2-phenyl ethyl alcohol, 2-phenyl ethyl methyl ether, terpinen-4-ol, 3-hydroxy2-isopropenyl-dihydrobenzofuran-5-carboxylic acid methyl ester, 3-methyl-3-buten-1yl acetate, 3-methyl-3-1 YL-Cinnamate, 3-methyl-3-buten-1yl-acetate-3-methyl-2-buten-1-ylcinnamate, 3,4-bis(4-hydroxy-3-methoxy benzyl) tetrahydrofuran, $\alpha$-terpineol, $\beta$-carotene, $\beta$-sitosterol, benzyl-benzoate, pinoresinol, germacrene $\mathrm{B}$, vitamin $\mathrm{C}$, vinidine, tangerine, 5,8-hydroxy-7-methoxy-flavon. The leaves contain the pyridine alkaloids, pandamarilactone- $1\left(\mathrm{C}_{18} \mathrm{H}_{23} \mathrm{NO}_{4}\right)$, pandamarilactone-31 $\left(\mathrm{C}_{19} \mathrm{H}_{25} \mathrm{NO}_{4}\right)$, and pandamarilactone-32 $\left(\mathrm{C}_{18} \mathrm{H}_{21} \mathrm{NO}_{3}\right)$. The aroma compound 2-acetyl-1-pyrollidine hasbeen identified from the volatile oil of the leaf [5]. Lignans andbenzofurans have been isolated from roots of Pandanus odoratissimus $[6,7]$.

The evaluation of these plants and of their active natural principles is a logic way of searching for new drugs to treat this disease. Pandanus odoratissimus is said to be restorative, indolent, promoting a feeling of well-being, and acting as a counter to tropical climates. Ayurvedic science has found the medicinal action of essential oil yielded by the screw pine's highly scented flowers to be useful in headaches and earaches and as a liniment for rheumatic pains.

It may be chewed as a breath sweetener or used as a preservative in foods. It is also believed to have health-related properties, including antiviral, antiallergy, antiplatelet, antiinflammatory, antioxidant, and anticancer action. Pandanus odoratissimus is said to be restorative, indolent, promoting a feeling of well-being, and acting as a counter to tropical climates [8].

The leaves of the plant have been mentioned valuable in leprosy, scabies, leucoderma, cephalalgia, coxalgia and otalgia, wounds, ulcers and colic, antioxidants [9]. The oil of the male flowers is considered stimulant and antispasmodic and is administered for headache and rheumatism $[10]$.

\section{Materials and Methods}

2.1. Collection and Selection of Plant Material Preparation of Extract. Fresh "Kewda" (Pandanus odoratissimus Linn) medicinal plants were collected from the surroundings of Lonavala Hill Station, Pune, Maharashtra (India), in April 2009 (Figure 1) and authenticated by the Botanical Survey of India, Pune, Maharashtra, India (voucher number MIM_PPA-18). Selected plant was powdered and material was separately weighed and used for extraction by the basis of polarity of solvent $[6,11-14]$. The concurrent extraction (maceration) of powdered plant material $(1 \mathrm{Kg})$ was soaked in 2.5 litres of (99.9\% Ethanol + Distilled Water) $(60: 40)$ hydroethanol for 7 days at room temperature. After 7 days, the hydroethanol soluble materials of both plants were filtered off separately $[10,15]$.

2.2. Subfraction Lyophilisation of Hydroethanol Extract. They were filtered and kept at room temperature for cooling. Aqueous extract was freezed under $-70^{\circ} \mathrm{C}$ for three days and then lyophilized. $1 \mathrm{~g}$ of lyophilized Pandanus odoratissimus Linn (LEPO) is equivalent to $2.01 \mathrm{~g}$ of dried Pandanus odoratissimus Linn hypocotyls. Lyophilized plant extract was diluted in distilled water to obtain a dose of $1 \mathrm{~g} / \mathrm{kg}$ b.w. This dose has been proved to be optimal in a dose-dependent study $[11,12]$.

2.3. Selection of Experimental Animals. Albino mice (Swiss strain) of either sex weighing between 18 and $25 \mathrm{~g}$ were procured from central animal house serum Institute, Hadapsar, Pune, for experimental purpose. After procuring, the animals were acclimatized for seven days under standard husbandry condition with 12:12 hours light or dark cycle.

Healthy Swiss Albino mice the chosen experimental animals were maintained in our animal house (12:12 dark: light cycle), with adequate ventilation and hygienic conditions, maintained with normal pelleted diet (NUTRIVATE life science, Sinhagad Road, Pune, Baramati Agro Ltd. 


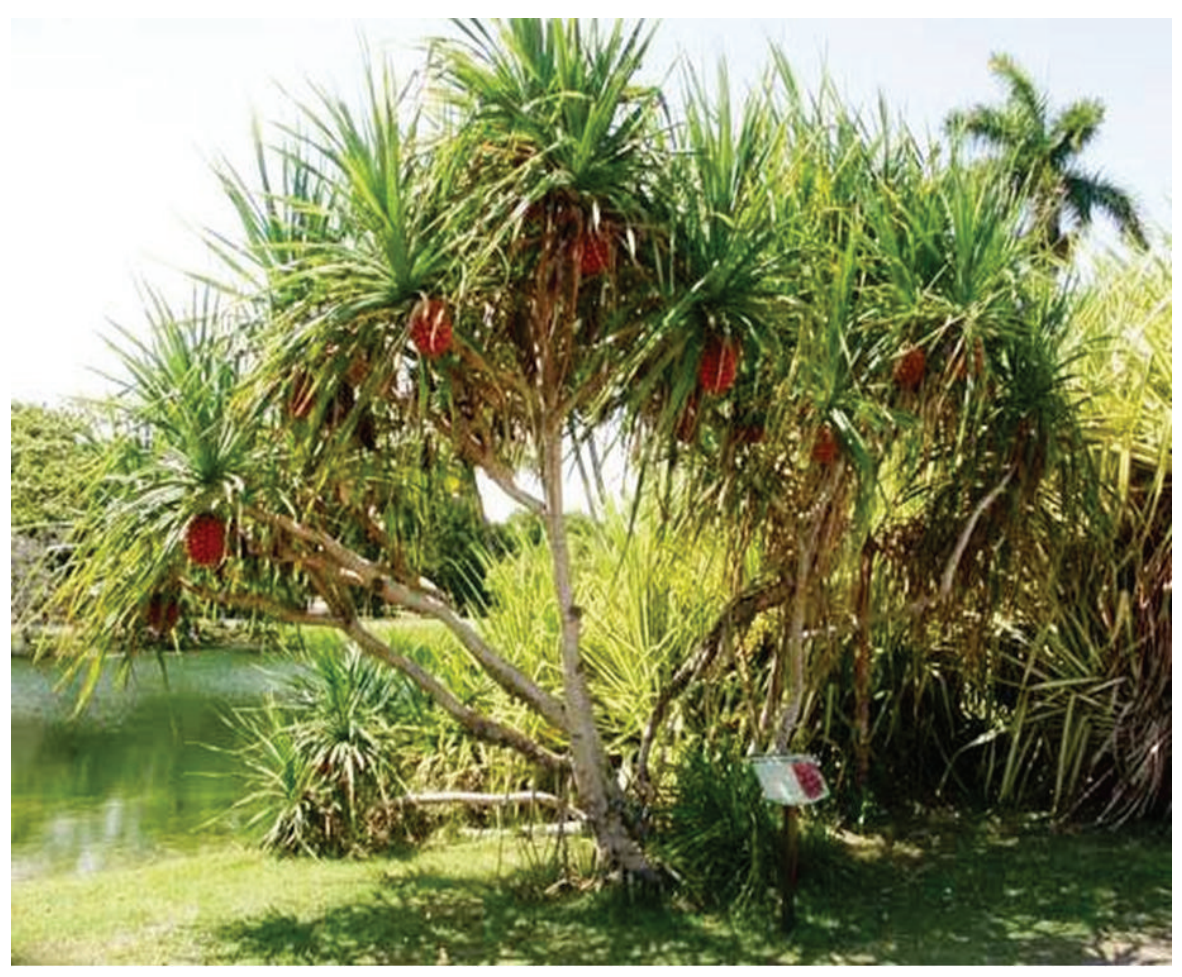

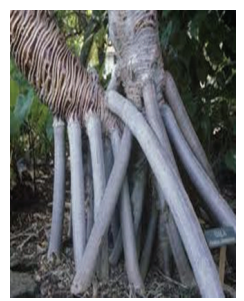

Roots and stem

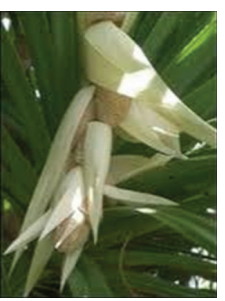

Leaves and flower

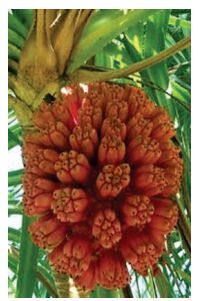

Ripped fruit

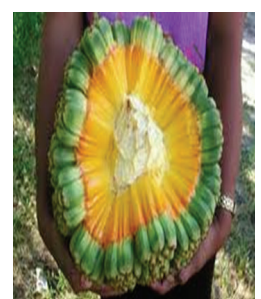

Fresh edible fruit

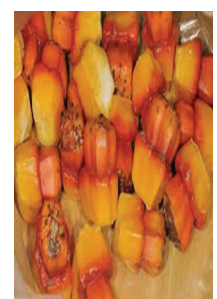

Edible pericarp

Figure 1: Plant monograph of Pandanus odoratissimus Linn (Kewda).

BVQI certified company) and water ad libitum. A group of animals were housed in polypropylene cage, paddy husk bed covered with stainless steel wire mesh with provision for water and feed. After obtaining prior permission from Institutional Animal Ethical Committee (IAEC) Protocol approval number JSCOPR/IAEC/02/2008-09, all animals' studies were performed in accordance with guidelines of "Committee for the Purpose of Control and Supervision of Experiments on Animals" (CPCSEA), Ministry of environment and Forest, Government of India.

2.4. Drugs and Chemicals Used. Drugs and chemicals used were as follows:

(i) marketed sample of Withania somnifera; Ashwagandha, 60 Caplets Himalaya Herbal Healthcare, Bangalore, India;

(ii) marketed sample of Pandanus odoratissimus; Kewra Water (Kewda Water), Top-Op; Spice of India, India.

2.5. Acute Toxicity Study. Acute oral toxicity study for the proprietary formulation was carried out using OECD guide- line-425 (modified, adopted March 23, 2006), the sequential test that uses a maximum of five animals. A test dose of 2000 or exceptionally $5000 \mathrm{mg} / \mathrm{kg}$ may be used in situation where experiment has information indicating that the test material is likely to be nontoxic.

The test procedure minimizes the number of animals required to estimate the oral acute toxicity of a chemical and in addition estimation of $\mathrm{LD}_{50}$, confidence intervals. The test also allows the observation of signs of toxicity and can also be used to identify chemicals that are likely to have low toxicity $[11,12]$.

As suggested, after acclimatization of animals for 4-5 days, study was carried out as follows. Healthy, young adult Albino Swiss mice (18-25 gm), nulliparous, and nonpregnant were used for this study. Food, but not water, was withheld for 3-4 hours and further 1-2 hours after administration of sample under study. One animal was received test drug (Plant extract) by oral route. Since this first test animal survived, four other animals were dosed (orally) at subsequent days, so that a total of five animals were tested.

Animals were observed individually at least every 5 minutes once during first 30 minutes after dosing, periodically at 
TABLE 1: Observation (AOT) report on acute oral toxicity test.

Sample: hydroethanol extract of Pandanus odoratissimus

Test guideline OECD 425 (modified October 2006) limit test

Animal used: Albino Swiss mice

Sex: female albino Swiss mice

Weight range: $18-25 \mathrm{gm}$

Route of drug administration: per oral

Dose: $2000 \mathrm{mg} / \mathrm{kg}$

Fasted for 3-4 hrs (before experimentation) and 1-2 hrs (after experimentation)

\begin{tabular}{|c|c|c|c|c|}
\hline \multirow{2}{*}{$\frac{\text { No. of animal used }}{3}$} & \multicolumn{4}{|c|}{ Date of testing } \\
\hline & & & & \\
\hline \multicolumn{5}{|l|}{3} \\
\hline Observations & $1 / 2 \mathrm{hr}$ & $1 \mathrm{hr}$ & $2 \mathrm{hr}$ & $4 \mathrm{hr}$ \\
\hline Awareness & 4 & 4 & 4 & 4 \\
\hline Mood & 0 & 0 & 0 & 0 \\
\hline Motor activity & 6 & 6 & 6 & 6 \\
\hline \multicolumn{5}{|l|}{ Neurological profile } \\
\hline (a) Central excitation & 0 & 0 & 0 & 0 \\
\hline (b) Muscle tone & 4 & 4 & 4 & 4 \\
\hline (c) Motor incoordination & 0 & 0 & 0 & 0 \\
\hline (d) Reflexes & 4 & 4 & 4 & 4 \\
\hline (f) Autonomic profile & 4 & 4 & 4 & 4 \\
\hline \multicolumn{5}{|l|}{ Screening sign } \\
\hline (a) Urination & 0 & 0 & 0 & 0 \\
\hline (b) Salivation & 0 & 0 & 0 & 0 \\
\hline \multicolumn{5}{|l|}{ General sign } \\
\hline Skin color & 4 & 4 & 4 & 4 \\
\hline Heart rate & 4 & 4 & 4 & 4 \\
\hline Respiratory rate & 4 & 4 & 4 & 4 \\
\hline Death & - & - & - & - \\
\hline
\end{tabular}

Inference: at $2000 \mathrm{mg} / \mathrm{kg}$ sample did not produce any observable toxic effects during entire duration of study and all animals survived 14 days of observation.

Conclusion: $\mathrm{LD}_{50}$ of test is $2000 \mathrm{mg} / \mathrm{kg}$.

2 hrs during the first 24 hours (with special attention during the first four hours), and daily thereafter, for a total of 14 days (Table 1).

\section{Experimental Pharmacology}

3.1. Scheduled Drug Treatments. Swiss albino mice (18-25 g) were for forced swim endurance stress test. The animals were divided into 5 groups consisting of 6 animals in each group. Group I was treated with saline water $(1 \mathrm{~mL})$. Group II was taken as a standard and was with treated with WS $(100 \mathrm{mg} / \mathrm{kg}$ p.o). Group III was treated with marketed preparation of Pandanus odoratissimus Linn. (PO) $(1 \mathrm{~mL} / \mathrm{kg})$ and Groups IV and $\mathrm{V}$ were taken as test groups and treated with $(100 \mathrm{mg} / \mathrm{kg}$ and $200 \mathrm{mg} / \mathrm{kg} \mathrm{p.o)} \mathrm{of} \mathrm{the} \mathrm{LEPO,} \mathrm{respectively,} \mathrm{for} \mathrm{the} \mathrm{all}$ models, namely, forced swimming endurance stress test, anoxic stress tolerance test, and chronic cold resistant stress test.
3.2. Forced Swimming Endurance Stress Test. Swiss albino mice $(18-25 \mathrm{~g})$ were used for forced for forced swim endurance stress test. The animals were divided in to 5 groups and all were treated as mentioned above in scheduled drug treatments.

The drug treatment was given continuously for seven days (same dose daily). On the 8th day the mice were subjected to swimming stress by keeping them in polypropylene tank of dimension $37 \times 37 \times 30 \mathrm{~cm}$ filled with water to a height $25 \mathrm{~cm}$. Mice were allowed to swim till complete exhaustion and the end point was taken when animal starting drowning. The mean swimming time for each group was calculated. The blood was collected through retroorbital puncture to estimate biochemical parameters like Serum glucose and Corticosterone and blood cells $[1,16]$.

3.3. Anoxic Stress Tolerance Test. Swiss albino mice (18-25 g) were used for forced for anoxic stress tolerancetest. The 
animals were divided into 5 groups and all were treated as mentioned above in scheduled drug treatments.

Conical flasks of $250 \mathrm{~mL}$ capacity were used for the study. These flasks were made airtight using rubber cork before beginning the experiment. Each animal was kept in the airtight vessel and time was noted using a stopwatch. The moment an animal showed first convulsion, it was removed immediately from the vessel and resuscitated if needed. The time duration from the entry of the animal in the hermetic (conical flask) vessel to the appearance of the first convulsion was taken as the time of "anoxic stress tolerance." The mean time to convulsion was recorded and animal was removed at onset of convulsion. The blood was collected through retroorbital puncture to estimate biochemical parameters like serum glucose and Corticosterone and blood cells $[1,17]$.

3.4. Chronic Cold Resistant Stress Test. Swiss albino mice (18$25 \mathrm{~g}$ ) were used for forced for chronic cold resistant stresstest. The animals were divided into 5 groups and all were treated as mentioned above in scheduled drug treatments.

The drug treatment was given continuously for seven days (same dose daily). In Each animals were subjected to cold stress by exposing them to $4 \pm 10^{\circ} \mathrm{C}$ daily for 2 hours. The extracts were administered daily once to respective groups. This procedure was repeated for a period of 7 days. Blood was collected through orbital plexus under light ether anesthesia to estimate biochemical parameters like blood glucose, corticosteroid, and blood cell count (RBC and DLC). Animals were sacrificed by giving excess euthanasia $[18,19]$.

3.5. Statistical Analysis. All values were expressed as mean \pm standard error of the mean. Result was analyzed statistically by using one-way ANOVA followed by Dunnett's multiple comparison test against the respective control. $P \leq 0.05$ were considered to be significant.

\section{Results}

In swimming test model, seven day treatment increased swimming time to $125,133,145$ by test drug and 416 by Withania sominifera as compare to control group $113 \mathrm{sec}$. Test Groups III, IV, and V swam for 125, 133, and $145 \mathrm{sec}$, respectively. When swimming time of Groups III, IV, and $\mathrm{V}$ was compared with Group I, it showed significant $(P<$ 0.01 ) rise in the swimming time. $200 \mathrm{mg} / \mathrm{kg}$ LEPO treated animals showed reading very close to $100 \mathrm{mg} / \mathrm{kg}$ of WS treated animals. Consequently higher dose of LEPO is more potent with respect to lower dose of extract. Both the doses were able to increase the swimming endurance when compared with animals who received normal saline water (Table 2).

4.1. Biochemical Parameter. On 8th day level of glucose in serum was found to be in control group (I) $141.6 \pm 1.6$. In the standard group which is treated with WS the serum glucose level was found to be $98.3 \pm 4.4 \mathrm{mg} / \mathrm{dL}$, and the test control groups (III, IV and V) treated with PO, LEPO $(100 \mathrm{mg} / \mathrm{kg})$
TABLE 2: Effect of LEPO on swimming survival time (sec) for forced swimming endurance test in Swiss Albino mice for 7-day study.

\begin{tabular}{lcc}
\hline Groups & $\begin{array}{c}\text { Treatment, dose } \\
\text { (mg/kg body wt.) p.o }\end{array}$ & $\begin{array}{c}\text { Swimming survival } \\
\text { time }(\mathrm{sec})\end{array}$ \\
\hline $\begin{array}{l}\text { Group I; negative } \\
\text { control }\end{array}$ & Saline water $(1 \mathrm{~mL})$ & $113 \pm 2.9$ \\
$\begin{array}{l}\text { Group II; } \\
\text { positive control }\end{array}$ & WS; (100) & $416.6 \pm 3.8^{* *}$ \\
$\begin{array}{l}\text { Group III; } \\
\text { test control }\end{array}$ & PO; (Kewda water) & $125.6 \pm 3.2^{*}$ \\
$\begin{array}{l}\text { Group IV; } \\
\text { test control }\end{array}$ & LEPO $(100)$ & $133.3 \pm 2.4^{* *}$ \\
$\begin{array}{l}\text { Group V; } \\
\text { test control }\end{array}$ & LEPO (200) & $145 \pm 3.8^{* *}$ \\
\hline
\end{tabular}

$n=6$ animals in each group.

WS: Withania somnifera; LEPO: lyophilized hydroethanol extract of leaves of Pandanus odoratissimus Linn; PO; (Kewda water): marketed preparation of Pandanus odoratissimus.

Values are mean \pm S.E.M. expressed of each group. Data analysis was performed using one-way ANOVA followed by Dunnett's multiple comparison test against the respective control. ${ }^{*} P<0.5,{ }^{* *} P<0.01$.

and LEPO $(200 \mathrm{mg} / \mathrm{kg})$ serum glucose level were showed the $105 \pm 2.8,110 \pm 1.0$ and $131.6 \pm 1.6$ simultaneously. The level of glucose was increased during the time of stress but it came down due to pretreatment of LEPO.

The level of Corticosterone in serum (on 8th day) was recorded as $140 \mathrm{mg} / \mathrm{dL}$ for control group for control groupI, who received by saline water. and the group-II treated with WS (withania somnifera) was found to have the $107.3 \pm$ $6.3 \mathrm{mg} / \mathrm{dL}$ level of Corticosterone in serum.

Groups III, IV, and V which were treated with marketed preparation of PO (Kewda water), LEPO 100, and $200 \mathrm{mg} . \mathrm{kg}$, respectively, demonstrate the Corticosterone level in plasma $123.6 \pm 1.6,126.6 \pm 3.3,126.6 \pm 1.6 \mathrm{mg} / \mathrm{dL}$, respectively; marketed sample of PO (Kewda water) showed significant decrease in the level of Corticosterone (Table 4).

4.2. Hematological Parameters. On 8th day all animal groups hematological parameters were checked the group-I, served as normal control treated with saline water, group-II, served as slandered control treated with WS, in the RBC count parameter were found as 9.3 and 7.53 million/cumm simultaneously. The RBC count of Groups III, IV, and V was found to be $8.53,7.56$, and 7.93 million/cumm with respect to Group I in which it reduced due to pretreatment of extracts. The neutrophils count of animals of Groups I, II, III, and IV was as found to be $13.3,10.3,11.29,12.3$, and $12.3 \%$, respectively. The neutrophils count of Groups II, III, and IV reduced due to pretreatment of extracts with respect to Group I. The lymphocytes count of animals of Groups I, II, III, IV, and V was found as 59.66, 55.33, 56.98, 59.6, and 58.33\%, respectively. The lymphocyte count of Groups III and IV reduced due to pretreatment of extracts with respect to Group I. The eosinophil count of animals of Group I, II, III, IV, and V was found as $3.3,1.4,2.1,2.6$, and 1.5 , respectively. The eosinophil count of groups III and IV reduced due to pretreatment of extracts with respect to Group I. The monocyte count of 
TABLE 3: Effect of LEPO on hematological parameters for forced swimming endurance test in Swiss Albino mice for 7-day study.

\begin{tabular}{|c|c|c|c|c|c|c|}
\hline \multirow{2}{*}{ Groups } & \multirow{2}{*}{$\begin{array}{l}\text { Treatment, dose mg/kg } \\
\text { body wt. p.o }\end{array}$} & \multicolumn{5}{|c|}{ Hematological parameters in values are mean \pm S.E.M. } \\
\hline & & RBCS & Neutrophils & Lymphocytes & Monocytes & Eosinophils \\
\hline $\begin{array}{l}\text { Group I; } \\
\text { negative control }\end{array}$ & Saline water $(1 \mathrm{~mL})$ & $9.3 \pm 0.3$ & $13.3 \pm 0.6$ & $59.66 \pm 0.3$ & $3.00 \pm 0.5$ & $3.3 \pm 0.3$ \\
\hline $\begin{array}{l}\text { Group II; } \\
\text { positive control }\end{array}$ & WS; (100) & $7.53 \pm 0.3^{* *}$ & $10.33 \pm 0.3^{* *}$ & $55.33 \pm 0.3^{* *}$ & $1.00 \pm 0.0^{*}$ & $1.3 \pm 0.3^{* *}$ \\
\hline $\begin{array}{l}\text { Group III; } \\
\text { test control }\end{array}$ & PO; (Kewda water) (0.5) & $8.53 \pm 0.1$ & $11.29 \pm 0.3^{*}$ & $56.98 \pm 0.3^{* *}$ & $1.40 \pm 0.3^{*}$ & $1.5 \pm 0.3^{* *}$ \\
\hline $\begin{array}{l}\text { Group IV; } \\
\text { test control }\end{array}$ & LEPO; (100) & $7.56 \pm 0.03^{* *}$ & $12.33 \pm 0.3$ & $59.66 \pm 0.6$ & $1.60 \pm 0.3$ & $2.0 \pm 01^{*}$ \\
\hline $\begin{array}{l}\text { Group V; } \\
\text { test control }\end{array}$ & LEPO; (200) & $7.93 \pm 0.1^{* *}$ & $13.01 \pm 0.3$ & $58.00 \pm 0.5^{*}$ & $1.30 \pm 0.3^{*}$ & $1.6 \pm 0.3^{* *}$ \\
\hline
\end{tabular}

$n=6$ animals in each groups.

WS: Withania somnifera; LEPO: lyophilized hydroethanol extract of leaves of Pandanus odoratissimus Linn; PO; (Kewda water): marketed preparation of Pandanus odoratissimus.

Values are mean \pm S.E.M. expressed of each group. Data analysis was performed using one-way ANOVA followed by Dunnett's multiple comparison test against the respective control. ${ }^{*} P<0.5,{ }^{*}{ }^{*} P<0.01$.

TABLE 4: Effect of LEPO on biochemical parameters in forced swimming endurance test in Swiss Albino mice for 7-day study.

\begin{tabular}{|c|c|c|c|}
\hline Groups & $\begin{array}{c}\text { Treatment, dose } \mathrm{mg} / \mathrm{kg} \text { body wt. } \\
\text { p.o }\end{array}$ & Reducing sugar & Corticosterone \\
\hline $\begin{array}{l}\text { Group I; } \\
\text { negative control }\end{array}$ & Saline water $(1 \mathrm{~mL})$ & $141.6 \pm 1.6$ & $140.0 \pm 1.6$ \\
\hline $\begin{array}{l}\text { Group II; } \\
\text { positive control }\end{array}$ & WS; (100) & $98.3 \pm 4.4^{* *}$ & $107.3 \pm 6.3^{* *}$ \\
\hline $\begin{array}{l}\text { Group III; } \\
\text { test control }\end{array}$ & PO; (Kewda water) (0.5) & $105 \pm 2.8^{* *}$ & $123.6 \pm 1.6^{*}$ \\
\hline $\begin{array}{l}\text { Group IV; } \\
\text { test control }\end{array}$ & LEPO; (100) & $131.6 \pm 1.6$ & $126.6 \pm 3.3^{*}$ \\
\hline $\begin{array}{l}\text { Group V; } \\
\text { test control }\end{array}$ & LEPO; (200) & $110.0 \pm 1.0^{* *}$ & $126.6 \pm 1.6^{*}$ \\
\hline
\end{tabular}

$n=6$ animals in each group.

WS: Withania somnifera; LEPO: lyophilized hydroethanol extract of leaves of Pandanus odoratissimus Linn; PO; (Kewda water): marketed preparation of Pandanus odoratissimus.

Values are mean \pm S.E.M. expressed of each group. Data analysis was performed using one-way ANOVA followed by Dunnett's multiple comparison test against the respective control. ${ }^{*} P<0.5,{ }^{* *} P<0.01$.

animals of Groups I, II, III, and IV was found as 3, 1, 1.6, 1.3 , and $1.3 \%$, respectively. The monocyte count of Groups IV and $\mathrm{V}$ reduced due to pretreatment of extracts with respect to Group I. Consequently forced swimming endurance test significantly altered the hematological parameters, that is, decreased RBC and DLC counts. Pretreatment with WS and LEPO significantly $(P<0.01)$ inhibited the stress induced changes in these parameters. On the other hand these values also express that higher dose of LEPO was very effective, but both the doses of test drug had shown significant adaptogenic activity (Table 3 ).

In anorexia stress tolerance test Group I (control) treated with saline water $(1 \mathrm{~mL})$ was kept in hermetic vessel to for $18.33 \mathrm{~min}$. Group II taken as a standard treated with Withania somnifera survive in hermetic vessel for $69 \mathrm{~min}$; Groups III, IV, and V animals survive in hermetic vessel 41, 33 , and $28 \mathrm{~min}$, respectively. The anoxia tolerance test was determined by taking the appearance of convulsion as end point. The LEPO at two doses (100 and $200 \mathrm{mg} / \mathrm{kg})$ and PO (Kewada water) at dose $(1 \mathrm{~mL})$ showed significant $(P<0.01)$ increasing tolerance stress time in 8th day as compared with the control (Table 5).

4.3. Biochemical Parameters for Anorexia Stress Tolerance Test. On 8th day level of glucose in serum control group (I) was found to be 120.33; in the standard group which is treated with WS the serum glucose level it was found to be $81.6 \pm$ $1.6 \mathrm{mg} / \mathrm{dL}$. In the test drug groups (III, IV, and V), $95 \pm$ $2.8,111.6 \pm 1.6$, and $101.33 \pm 0.6$, the level of glucose was increased during the time of stress but it came down due to pretreatment of LEPO. The level of Corticosterone in serum (on 8th day) was recorded as $141 \pm 1.6 \mathrm{mg} / \mathrm{dL}$ for control group who served by Saline water $(1 \mathrm{~mL})$. Group-II, treated with WS, and corticosterone level were found as the $85 \pm$ $2.8 \mathrm{mg} / \mathrm{dL}$ level of Corticosterone in serum. Groups III, IV, and $\mathrm{V}$ which were treated with marketed preparation of $\mathrm{PO}$ (Kewda water) and LEPO 100 and $200 \mathrm{mg} / \mathrm{kg}$, respectively, demonstrate the Corticosterone level in plasma $103.3 \pm 1.6$, $118.3 \pm 4.4$, and $110 \pm 5.7 \mathrm{mg} / \mathrm{dL}$, respectively. $200 \mathrm{mg} / \mathrm{kg}$ of LEPO and marketed sample of Pandanus odoratissimus Linn 
TABLE 5: Effect of LEPO on duration of anorexic stress tolerance for anorexic stress tolerance test in Swiss Albino mice for 7-day study.

\begin{tabular}{|c|c|c|}
\hline Groups & $\begin{array}{l}\text { Treatment, dose } \\
\text { mg/kg body wt. p.o }\end{array}$ & $\begin{array}{l}\text { Duration of anoxic } \\
\text { stress tolerance }(\mathrm{min}) \\
\text { mean } \pm \mathrm{SE}\end{array}$ \\
\hline $\begin{array}{l}\text { Group I; } \\
\text { negative control }\end{array}$ & Saline water $(1 \mathrm{~mL})$ & $18.33 \pm 0.6$ \\
\hline $\begin{array}{l}\text { Group II; } \\
\text { positive control }\end{array}$ & WS; (100) & $69.05 \pm 1.2^{* *}$ \\
\hline $\begin{array}{l}\text { Group III; } \\
\text { test control }\end{array}$ & $\begin{array}{c}\text { PO; (Kewda water }) \\
(0.5)\end{array}$ & $41.83 \pm 2.0^{* *}$ \\
\hline $\begin{array}{l}\text { Group IV; } \\
\text { test control }\end{array}$ & LEPO; (100) & $28.67 \pm 0.8^{* *}$ \\
\hline $\begin{array}{l}\text { Group V; } \\
\text { test control }\end{array}$ & LEPO; (200) & $33.83 \pm 0.9^{* *}$ \\
\hline
\end{tabular}

$n=6$ animals in each group.

WS: Withania somnifera; LEPO: lyophilized hydroethanol extract of leaves of Pandanus odoratissimus Linn; PO; (Kewda water): marketed preparation of Pandanus odoratissimus.

Values are mean \pm S.E.M. expressed of each group. Data analysis was performed using one-way ANOVA followed by Dunnett's multiple comparison test against the respective control. ${ }^{*} P<0.5,{ }^{* *} P<0.01$.

(PO; Kewda water) showed significant decrease in the level of Corticosterone (Table 7).

\subsection{Hematological Parameters for Anorexia Stress Tolerance} Test. On 8th day RBC count of animals of Group I treated as control, Group II treated as a standard, Group III for marketed preparation PO (Kewda water), and Groups IV and $\mathrm{V}$ treated with LEPO was found as 10.3, 7.4, 7.5, 7.6, and 7.6 million/cumm, respectively. The RBC count of Groups III, IV, and $\mathrm{V}$ with respect to Group I reduced due to pretreatment of extracts. The neutrophils count of animals of Groups I, II, III, and IV was found as 16, 10.3, 10.6, 11.05, and 11.3\%, respectively. The neutrophils count of Groups III and V reduced due to pretreatment of marketed sample and extracts with respect to Group I. The lymphocytes count of animals of Groups I, II, III, and IV was found as 66, 50.6, 53.6, 58, and $54.6 \%$, respectively. The lymphocyte count of Groups III, $\mathrm{IV}$, and $\mathrm{V}$ reduced due to pretreatment of marketed sample and extracts with respect to Group I. The eosinophil count of animals of Groups I, II, III, IV, and V was found as $3,0.6,1,1.3$, and 1.3, respectively. The eosinophil count of Groups II, III, and IV reduced due to pretreatment of PO (Kewda water) and extracts with respect to Group I. The monocyte count of animals of Groups I, II, III, and IV was found as $3.3,1.3,1.3,1.6$, and $1.6 \%$, respectively. The monocyte count of Groups II, III, and IV reduced due to pretreatment of extracts with respect to Group I. Consequently anoxia stress tolerance test significantly altered the hematological parameters, that is, increased RBC and DLC counts. Pretreatment with marketed sample and extracts significantly $(P<0.01)$ inhibited the stress induced changes in these parameters. On the other hand, these values also express that higher dose of LEPO was very effective, but both the doses of test drug had shown significant adaptogenic activity (Table 6).
4.5. Biochemical Parameters for Chronic Cold Resistance Test. On 8th day level of glucose in serum control group (I) was found to be $116 \pm 1.6$. In the standard group which is treated with WS the serum glucose level was found to be $70 \pm 3.1 \mathrm{mg} / \mathrm{dL}$. In the test drug Groups III, IV, and V, $101.6 \pm 1.6,112.3 \pm 1.4,116.6 \pm 3.3$, the level of glucose was increased during the time of stress but it came down due to pretreatment of PO (Kewda water) and LEPO.

The level of Corticosterone in serum (on 8th day) was recorded as $143.3 \pm 1.6 \mathrm{mg} / \mathrm{dL}$ for control Group I Saline water $(1 \mathrm{~mL})$. Group II treated with WS was found to have the $104.6 \pm 2.4 \mathrm{mg} / \mathrm{dL}$ level of Corticosterone in serum.

Groups III, IV, and V which were treated with marketed preparation PO (Kewda water) and LEPO 100 and $200 \mathrm{mg} \cdot \mathrm{kg}$, respectively, demonstrate the Corticosterone level in plasma $110 \pm 5.7,118 \pm 1.6$, and $113.3 \pm 6.6 \mathrm{ng} / \mathrm{dL}$, respectively. Marketed sample and LEPO showed significant decrease in the level of Corticosterone (Table 9).

4.6. Hematological Parameter for Chronic Cold Resistance Test. On 8th day in Group I treated as control and Group II treated as a standard with WS, the RBC count for animals was found as 9.6 and 7.4 million/cumm. The RBC count of Groups III, IV, and IV was found to be 7.5, 7.9, and 7.7 million/cumm with respect to Group I in which it reduced due to pretreatment of marketed sample and extracts. The neutrophils count of animals of Groups I, II, III, and IV was found as 13.3, 10.3, 10.6, 11.3 , and $11.6 \%$, respectively. The neutrophils count of Groups II, III, and IV reduced due to pretreatment of marketed sample and extracts with respect to Group I. The lymphocytes count of animals of Groups I, II, III, IV, and V was found as $61.6,52,52.3,56$, and $55 \%$, respectively. The lymphocyte count of Groups III and IV reduced due to pretreatment of extracts with respect to Group I. The eosinophil count of animals of Groups I, II, III, IV, and V was found as 3.3, 1.3, 1.6, 1.6 , and 1.3, respectively. The eosinophil count of Groups III and IV reduced due to pretreatment of extracts with respect to Group I. The monocyte count of animals of Groups I, II, III, and IV was found as $2.3,1,1.3,1.3$, and $1 \%$, respectively. The monocyte count of Groups IV and V reduced due to prtreatment of PO (Kewda water) and LEPO with respect to Group I. Consequently cold stress test significantly altered the hematological parameters, that is, decreased RBC and DLC counts. Pretreatment with WS and LEPO significantly $(P<0.01)$ inhibited the stress induced changes in these parameters. On the other hand these values also express that higher dose of LEPO was very effective, but both the doses of test drug had shown significant adaptogenic activity (Table 8).

\section{Discussion}

Stress alters the equilibrium of various hormones which have a significant impact on the immune response in general. The status of immune system immunosuppression versus immunopotentiation will depend upon the net effect of these changes. Stress has been shown to affect immune system functioning with both immunosuppression and immunopotentiation. 
TABLE 6: Effect of LEPO on hematological parameters for anorexia stress tolerance test in Swiss Albino mice for 7-day study.

\begin{tabular}{|c|c|c|c|c|c|c|}
\hline \multirow{2}{*}{ Groups } & \multirow{2}{*}{$\begin{array}{c}\text { Treatment, dose } \mathrm{mg} / \mathrm{kg} \text { body wt. } \\
\text { p.o }\end{array}$} & \multicolumn{5}{|c|}{ Hematological parameters in values are mean \pm S.E.M. } \\
\hline & & RBCS & Neutrophil & Lymphocyte & Monocyte & Eosinophils \\
\hline $\begin{array}{l}\text { Group I; } \\
\text { negative control }\end{array}$ & Saline water $(1 \mathrm{~mL})$ & $10.3 \pm 0.3$ & $16 \pm 1$ & 66 & $3.3 \pm 0.3$ & $3 \pm 0.5$ \\
\hline $\begin{array}{l}\text { Group II; } \\
\text { positive control }\end{array}$ & WS; (100) & $7.4 \pm 0.03^{* *}$ & $10.3 \pm 0.3^{* *}$ & $50.6 \pm 0.6^{* *}$ & $1.3 \pm 0.3^{* *}$ & $0.6 \pm 0.3^{* *}$ \\
\hline $\begin{array}{l}\text { Group III; } \\
\text { test control }\end{array}$ & PO; (Kewda water $)(0.5)$ & $7.5 \pm 0.1^{* *}$ & $10.6 \pm 0.3^{* *}$ & $53 \pm 1.5^{* *}$ & $1.3 \pm 0.3^{* *}$ & $1 \pm 0.0^{*}$ \\
\hline $\begin{array}{l}\text { Group IV; } \\
\text { test control }\end{array}$ & LEPO; (100) & $7.6 \pm 0.1^{* *}$ & $11 \pm 0.5^{* *}$ & $58.3 \pm 1.2^{*}$ & $1.6 \pm 0.3^{*}$ & $1.3 \pm 0.3^{*}$ \\
\hline $\begin{array}{l}\text { Group V; } \\
\text { test control }\end{array}$ & LEPO; (200) & $7.6 \pm 0.1^{* *}$ & $11.3 \pm 0.3^{* *}$ & $54.6 \pm 1.6^{* *}$ & $1.6 \pm 0.3^{*}$ & $1.3 \pm 0.3^{*}$ \\
\hline
\end{tabular}

$n=6$ animals in each group.

WS: Withania somnifera; LEPO: lyophilized hydroethanol extract of leaves of Pandanus odoratissimus Linn; PO; (Kewda water): marketed preparation of Pandanus odoratissimus.

Values are mean \pm S.E.M. expressed of each group. Data analysis was performed using one-way ANOVA followed by Dunnett's multiple comparison test against the respective control. ${ }^{*} P<0.5,{ }^{*} P<0.01$.

TABLE 7: Effect of LEPO on biochemical parameters in anorexia stress tolerance test in Serum in Swiss Albino mice for 7-day study.

\begin{tabular}{|c|c|c|c|}
\hline Groups & $\begin{array}{c}\text { Treatment, dose mg/kg body wt. } \\
\text { p.o }\end{array}$ & Reducing sugar & Corticosterone \\
\hline $\begin{array}{l}\text { Group I; } \\
\text { negative control }\end{array}$ & Saline water $(1 \mathrm{~mL})$ & $120.33 \pm 0.3$ & $141 \pm 1.6$ \\
\hline $\begin{array}{l}\text { Group II; } \\
\text { positive control }\end{array}$ & WS; (100) & $81.6 \pm 1.6^{* *}$ & $85 \pm 2.8^{* *}$ \\
\hline $\begin{array}{l}\text { Group III; } \\
\text { test control }\end{array}$ & PO; (Kewda water $)$ (0.5) & $95 \pm 2.8^{* *}$ & $103.3 \pm 1.6^{* *}$ \\
\hline $\begin{array}{l}\text { Group IV; } \\
\text { test control }\end{array}$ & LEPO; (100) & $111.6 \pm 1.6^{*}$ & $118.3 \pm 4.4^{* *}$ \\
\hline $\begin{array}{l}\text { Group V; } \\
\text { test control }\end{array}$ & LEPO; (200) & $101.33 \pm 0.6^{* *}$ & $110 \pm 5.7^{* *}$ \\
\hline
\end{tabular}

$n=6$ animals in each group.

WS: Withania somnifera; LEPO: lyophilized hydroethanol extract of leaves of Pandanus odoratissimus Linn; PO; (Kewda water): marketed preparation of Pandanus odoratissimus.

Values are mean \pm S.E.M. expressed of each group. Data analysis was performed using one-way ANOVA followed by Dunnett's multiple comparison test against the respective control. ${ }^{*} P<0.5,{ }^{*} P<0.01$.

TABLE 8: Effect of LEPO on hematological parameters cold endurance test in Swiss Albino mice for 7-day study.

\begin{tabular}{|c|c|c|c|c|c|c|}
\hline \multirow{2}{*}{ Groups } & \multirow{2}{*}{$\begin{array}{l}\text { Treatment, dose } \mathrm{mg} / \mathrm{kg} \text { body wt. } \\
\text { p.o }\end{array}$} & \multicolumn{5}{|c|}{ Hematological parameters in values are mean \pm S.E.M. } \\
\hline & & RBCS & Neutrophil & Lymphocyte & Monocyte & Eosinophils \\
\hline $\begin{array}{l}\text { Group I; } \\
\text { negative control }\end{array}$ & Saline water $(1 \mathrm{~mL})$ & $9.6 \pm 0.8$ & $13.6 \pm 0.3$ & $61.6 \pm 1.6$ & $3.3 \pm 0.3$ & $2.3 \pm 0.3$ \\
\hline $\begin{array}{l}\text { Group II; } \\
\text { positive control }\end{array}$ & WS; (100) & $7.4 \pm 0.03$ & $10.3 \pm 0.3^{* *}$ & $52.3 \pm 1.1^{* *}$ & $1.3 \pm 0.3^{* *}$ & $1^{* *}$ \\
\hline $\begin{array}{l}\text { Group III; } \\
\text { test control }\end{array}$ & PO; (Kewda water $)(0.5)$ & $7.5 \pm 0.17$ & $10.6 \pm 0.6^{* *}$ & $52 \pm 1.4^{*}$ & $1.3 \pm 0.3^{* *}$ & $1 \pm 0.6^{*}$ \\
\hline $\begin{array}{l}\text { Group IV; } \\
\text { test control }\end{array}$ & LEPO; (100) & $7.9 \pm 0.05$ & $11.6 \pm 0.3^{*}$ & $56 \pm 1.1^{*}$ & $1.6 \pm 0.3^{*}$ & $1.3 \pm 0.3$ \\
\hline $\begin{array}{l}\text { Group V; } \\
\text { test control }\end{array}$ & LEPO; (200) & $7.7 \pm 0.1$ & $11.3 \pm 0.3^{* *}$ & $55 \pm 0.5^{*}$ & $1.6 \pm 0.3^{*}$ & $1.3 \pm 0.3$ \\
\hline
\end{tabular}

$n=6$ animals in each group.

WS: Withania somnifera; LEPO: lyophilized hydroethanol extract of leaves of Pandanus odoratissimus Linn; PO; (Kewda water): marketed preparation of Pandanus odoratissimus.

Values are mean \pm S.E.M. expressed of each group. Data analysis was performed using one-way ANOVA followed by Dunnett's multiple comparison test against the respective control. ${ }^{*} P<0.5,{ }^{* *} P<0.01$. 
TABLE 9: Effect of LEPO on biochemical parameters in cold endurance test in Swiss Albino mice for 7-day study.

\begin{tabular}{lcc}
\hline Groups & $\begin{array}{c}\text { Treatment, dose } \mathrm{mg} / \mathrm{kg} \text { body wt. } \\
\text { p.o }\end{array}$ & Reducing sugar \\
\hline $\begin{array}{l}\text { Group I; } \\
\text { negative control }\end{array}$ & Saline water $(1 \mathrm{~mL})$ & $116 \pm 1.6$ \\
$\begin{array}{l}\text { Group II; } \\
\text { positive control }\end{array}$ & WS; (100) & $70 \pm 3.1^{* *}$ \\
$\begin{array}{l}\text { Group III; } \\
\text { test control }\end{array}$ & PO; (Kewda water) $(0.5)$ & $101.6 \pm 1.6^{* *}$ \\
$\begin{array}{l}\text { Group IV; } \\
\text { test control }\end{array}$ & LEPO; (100) & $116.6 \pm 3.3^{* *}$ \\
$\begin{array}{l}\text { Group V; } \\
\text { test control }\end{array}$ & LEPO; (200) & $104.6 \pm 2.4^{* *}$ \\
\hline
\end{tabular}

$n=6$ animals in each group.

WS: Withania somnifera; LEPO: lyophilized hydroethanol extract of leaves of Pandanus odoratissimus Linn; PO; (Kewda water): marketed preparation of Pandanus odoratissimus.

Values are mean \pm S.E.M. expressed of each group. Data analysis was performed using one-way ANOVA followed by Dunnett's multiple comparison test against the respective control. ${ }^{*} P<0.5,{ }^{*} P<0.01$.

Plant adaptogens are smooth prostressor which reduces the reactivity of host defense system and decreases the damaging effect of various stressors due to increase of basal level mediators involved in the stress response [20].

The forced swimming is the most widely used method for assessing the antistress property of a compound. This paradigm is based on the observation that animal when forced to swim in water eventually assumed characteristics immobile posture, devoid of any activity. The appearance of immobility, therefore, reflects a state of tiredness, fatigue, and reduced stamina with the end point being the moment when the mice could not swim further and started drowning $[3,18]$.

The increased swimming time has been observed in mice pretreated with Pandanus odoratissimus with enhanced physical performances significantly longer than untreated (control) group and thus confirmed selected Indian medicinal plants having the adaptogenic nature.

During stress, blood glucose level increases which are found to be significantly reduced in Pandanus odoratissimus treated mice. Lowering of stress induced hyperglycemia is an indication of Antistress, adaptogenic activity of plant.

In response to stress, ACTH is released, which acts on the adrenal cortex to stimulate the synthesis and release of cortisol [21]. Increased plasma cortisol influences the mobilization of stored fat and carbohydrate reserves which in turn increased blood glucose level. The increased cortisol levels are reversed by antistress agents [21]. LEPOsignificantly decreases the stress induced elevated levels of cortisol and blood glucose level. The reference drug in this study, WS, also produced similar result. Stressed animals spleen contracts and releases the more amounts of blood cells (RBC's and WBC's) into circulations. (this stage in acute stress phenomenon) [1,17]. The stress induced RBC and WBC count is decreased by the LEPO. Increased swim duration and decreased (this stage in chronic stress phenomenon) in $\mathrm{RBC}$ and WBC count in mice pretreated with Pandanus odoratissimus are similar to the changes produced by reference drug Withania somnifera.
Anorexia is a very sever stressor. All the body functions including cellular respiration depend on oxygen supply to them. Any lack of this vital element plays havoc on all body mechanisms. Increase in adaptation during this stress by any drug could be considered as its major antistress effect [3]. The result of the study demonstrates that the Pandanus odoratissimus extract significantly prolonged the meantime to convulsion, which therefore confirms its antistress property. Prolongation of meantime to convulsion could be a result of its powerful antioxidant and free radical scavenging activities $[3,18]$, the mechanism by which stress rises which enhances the activity of hypothalamo-hypophyseal axis (HPA) resulting in liberation of catecholamine and corticosteroids. The increase release of catecholamine leads to elevated levels of glucose. Stress induces adrenomedullary response in man. Adrenaline in turn stimulates $\beta_{2}$ receptor on the pituitary gland causing greater release of ACTH, which can stimulate the adrenal medulla as well as cortex. Cortisol increases mRNA level in liver cells. Spleen constricts to release more blood cells (RBC and WBC) during stress, so their weights decrease in stress [22]. This stress induced changes were significantly reversed by the test extract at lower and higher doses. Experimental studies have confirmed the adaptogenic activity of Pandanus odoratissimus.

Cold stress is a psychogenic type [23]. Response to stress is highly contradictory with regard to blood sugar level. A significant hyperglycemia in cold restraint stress model was observed. Under stressful condition Corticosterone in mice will be secreted by adrenal cortex. Hyper secretion of Corticosterone helps the maintenance of internal homeostasis through the process of gluconeogenesis [16]. The treatment with the lyophilized hydroethanol extract of leaves of Pandanus odoratissimus significantly reduced the cold stress related hyperglycemias. The re-ducting the hyperactivity of hormonal secretions of adrenal cortex and it's beneficial to maintain homeostatic mechanism [1].

Stress also causes the alteration in hematological parameter like increase in RBC and WBC [1]. Pretreatment with 
lyophilized hydroethanol extract of leaves of Pandanus odoratissimus (LEPO) and reference drug Withania somnifera (WS) reduced the hematological parameters significantly [19].

\section{Conclusion}

LEPO at dose of 100 and $200 \mathrm{mg} / \mathrm{kg}$ and the marketed sample have shown significantly that they possess the ability to prevent alteration due to stress. The above results are promising and further dose variant studies would be helpful in substantiating the claim of adaptogenic action of this drug.

Thus with all above results it can be claimed and concluded that the marketed and the lyophilized hydroethanol extract of leaves of Pandanus odoratissimus Linn (LEPO) have adaptogenic property.

\section{Conflict of Interests}

The authors declare that there is no conflict of interests regarding the publication of this paper.

\section{References}

[1] S. Puri, B. Kumar, J. Debnath et al., "Comparative pharmacological evaluation of adaptogenic activity of Holoptelea integrifolia and Withania somnifera," International Journal of Drug Development and Research, vol. 3, no. 1, pp. 84-98, 2011.

[2] C. O. Esimone, M. U. Adikwu, C. Nworu, S. C. Okoye, and D. C. Odimegwu, "Adaptogenic potentials of Camellia sinensis leaves, Garcinia kola and Kola nitida seeds," Scientific Research and Essays, vol. 2, no. 7, pp. 232-237, 2007.

[3] R. Sonkar and R. N. Mishra, "Adaptogenic activity of Triphala megaext," International Journal of Research in Pharmaceutical and Biomedical Sciences, vol. 2, no. 1, pp. 106-109, 2011.

[4] K. R. Khandelwal, Practical Pharmacognosy Techniques \& Experiments, Nirali prakashan, 14th edition, 2008.

[5] S. R. Chilkwad, K. P. Manjunath, K. S. Akki, R. V. Savadi, and N. Deshpande, "Pharmacognostic and Phytochemical investigation of leaves of Pandanus odoratissimus Linn.f.", Ancient Science of Life, vol. 28, no. 2, pp. 3-6, 2008.

[6] A. K. Nadkarni, Bombay: Popular Prakashan, vol. 1, Indian Material Medica, Mumbai, India, 2nd edition, 1993, 3rd edition, 1976.

[7] T.-T. Jong and S.-W. Chau, "Antioxidative activities of constituents isolated from Pandanus odoratissimus," Phytochemistry, vol. 49, no. 7, pp. 2145-2148, 1998.

[8] Anonymous, the Wealth of India. A dictionary of Indian Raw Material and Industrial Products, Vol. VII, Council of Scientific and Industrial Research, New Delhi, India, 1966.

[9] T. Jong and S. Chau, "Antioxidative activities of constituents isolated from Pandanus odoratissimus," Phytochemistry, vol. 49, no. 7, pp. 2145-2148, 1998.

[10] S. Rajuh, N. V. Subbaiah, K. S. Reddy, A. Das, and K. B. Murugan, "Potential of Pandanus odoratissimus as a CNS depressant in Swiss albino mice," Brazilian Journal of Pharmaceutical Sciences, vol. 47, no. 3, pp. 630-634, 2011.

[11] P. P. Adkar and V. H. Bhaskar, "Pandanus odoratissimus (Kewda): a review on ethnopharmacology, phytochemistry and nutritional aspects," Advances in Pharmacological Sciences. In press.
[12] P. P. Adkar, P. P. Jadhav, S. D. Ambavade, T. T. Shelke, and V. H. Bhaskar, "Protective effect of leaf extract of Pandanus odoratissimus Linn on experimental model of epilepsy," International Journal of Nutrition, Pharmacology, Neurological Diseases, vol. 4, pp. 81-87, 2014.

[13] S. Y. Sawant, Review of Pandanus odoratissimus Linn, Medicinal Plant of Maharashtra, Index no. 3, Continent Prakashan, Pune, India, Marathi edition, 2000.

[14] K. R. Kirtikar and B. D. Basu, Text Book of Indian Medicinal Plants, vol. 2, 2000.

[15] Anonymous, The Ayurvedic Pharmacopoeia of India, Ministry of Health \& Family Welfare, New Delhi, India, 1st edition, 1986.

[16] B. Singh, B. K. Chandan, and D. K. Gupta, "Adaptogenic activity of a novel withanolide-free aqueous fraction from the roots of Withania somnifera Dun. (Part II)," Phytotherapy Research, vol. 17, no. 5, pp. 531-536, 2003.

[17] B. Singh, A. K. Saxena, B. K. Chandan, D. K. Gupta, K. K. Bhutani, and K. K. Anand, "Adaptogenic activity of a novel, withanolide-free aqueous fraction from the roots of Withania somnifera Dun," Phytotherapy Research, vol. 15, no. 4, pp. 311318, 2001.

[18] M. Arif, S. Fareed, T. Hussain, and M. Ali, "Adaptogenic activity of lanostane triterpenoid isolated from Carissa carandas fruit against physically and chemically challenged experimental mice," Pharmacognosy Journal, vol. 5, no. 5, pp. 216-220, 2013.

[19] S. K. Bhattacharya and A. V. Muruganandam, "Adaptogenic activity of Withania somnifera: an experimental study using a rat model of chronic stress," Pharmacology Biochemistry and Behavior, vol. 75, no. 3, pp. 547-555, 2003.

[20] A. Panossian, G. Wikman, and H. Wagner, "Plant adaptogens III. Earlier and more recent aspects and concepts on their mode of action," Phytomedicine, vol. 6, no. 4, pp. 287-300, 1999.

[21] B. V. S. Lakshmi and M. Sudhakar, "Attenuation of acute and chronic restraint stress-induced perturbations in experimental animals by Zingiber officinale Roscoe," Food and Chemical Toxicology, vol. 48, no. 2, pp. 530-535, 2010.

[22] V. S. Pawar and S. Hugar, "Adaptogenic activity of Trigonella foenum graecum (Linn) seeds in rodents exposed to anoxia and immobilization stress," Asian Pacific Journal of Tropical Biomedicine, vol. 2, pp. S208-S211, 2012.

[23] D. M. Kannur, V. I. Hukkeri, and K. S. Akki, "Adaptogenic activity of Caesalpinia bonduc seed extracts in rats," Journal of Ethnopharmacology, vol. 108, no. 3, pp. 327-331, 2006. 

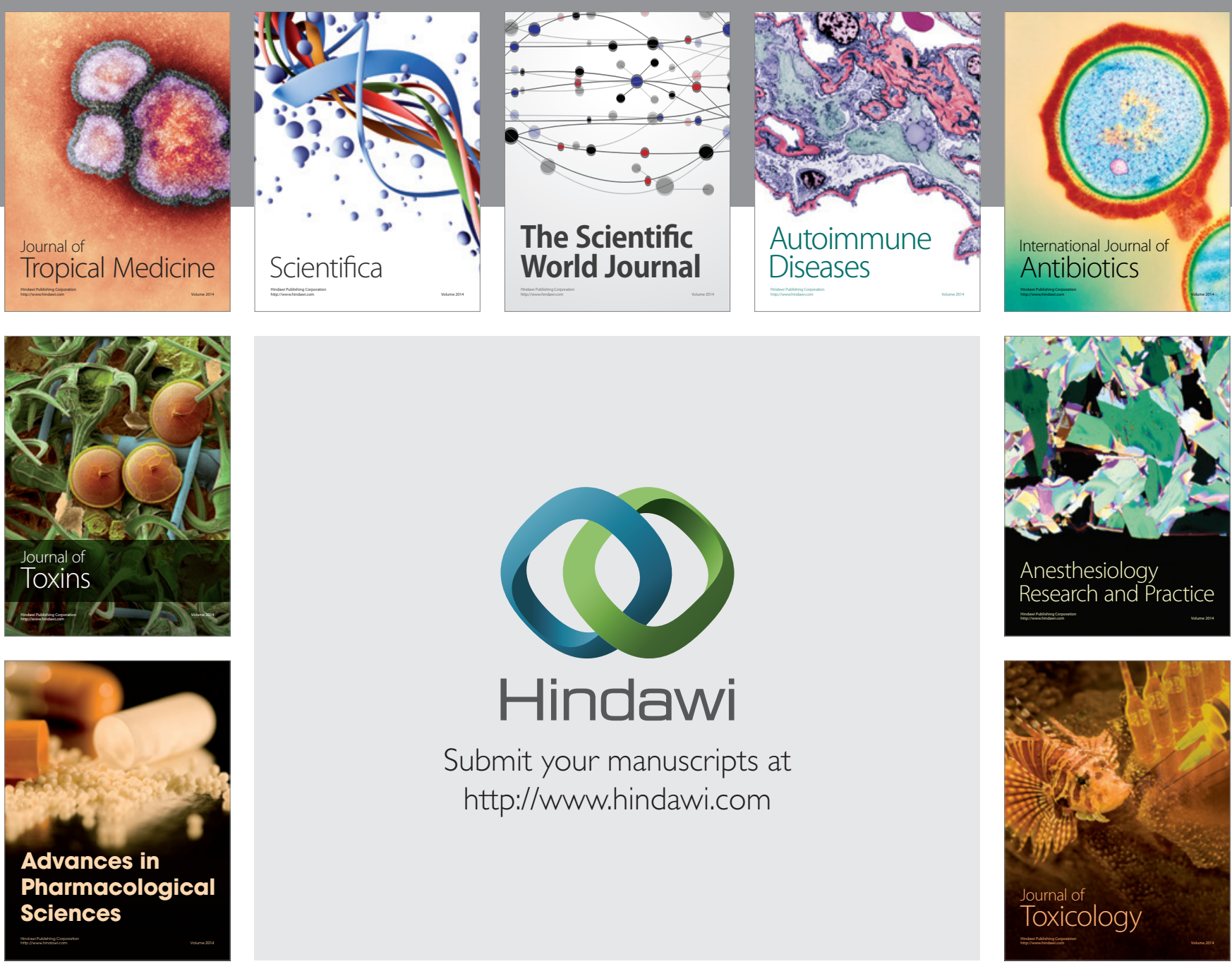

\section{Hindawi}

Submit your manuscripts at

http://www.hindawi.com
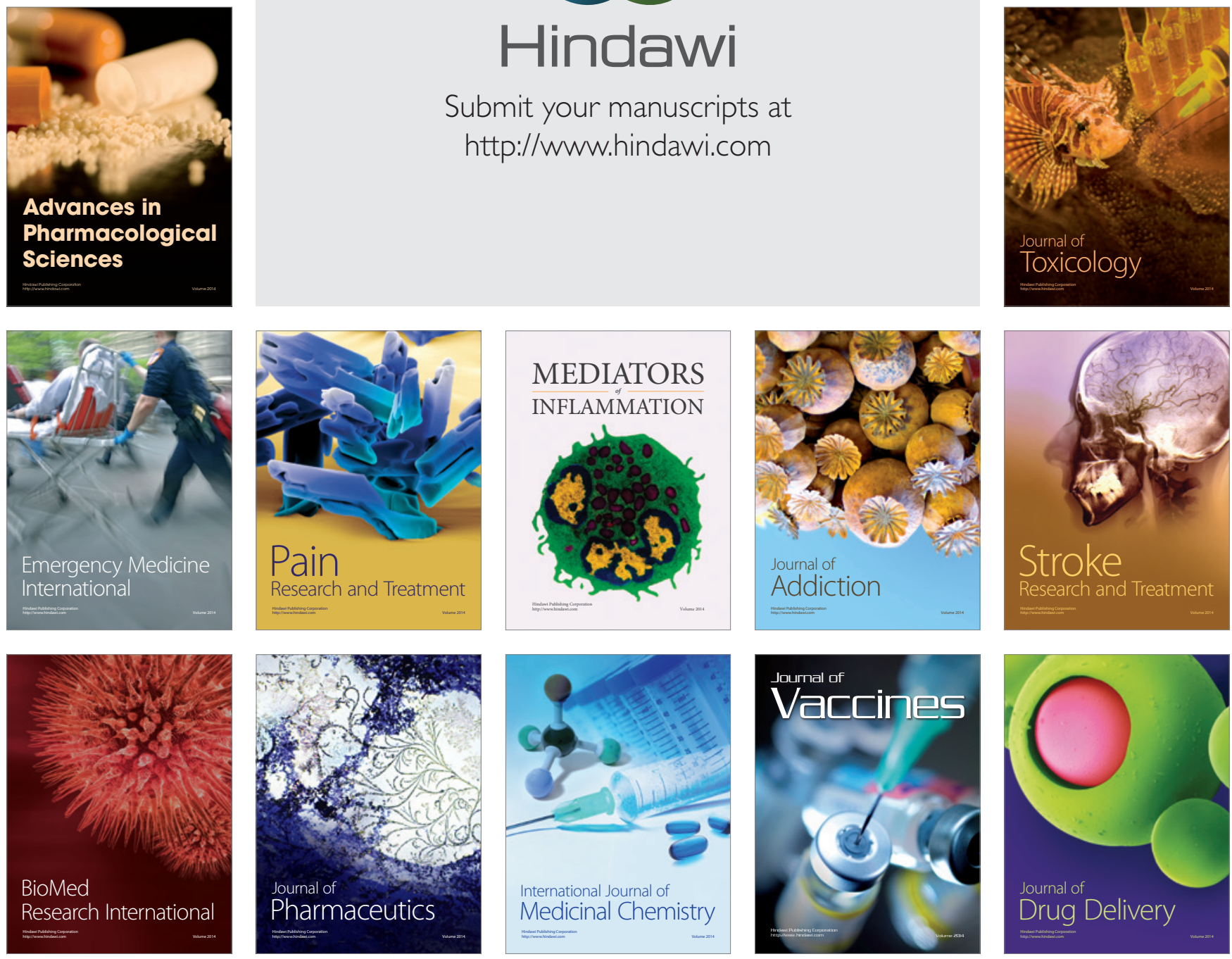